ISSN: 2637-4692

\title{
A Case Series: Zinc Deficiency as a Potential Contributor to Oral Dysgeusia
}

\author{
Guangzhao (Simon) Guan ${ }^{1 *}$ and Li (Peter) $\mathrm{Mei}^{2}$ \\ ${ }^{1}$ Department of Oral Diagnostic and Surgical Sciences, University of Otago, New Zealand \\ ${ }^{2}$ Department of Oral Sciences, University of Otago, New Zealand
}

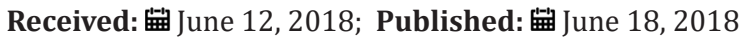

*Corresponding author: Guangzhao Guan, Department of Oral Diagnostic and Surgical Sciences, University of Otago, School of Dentistry, 310 Great King Street, Dunedin, New Zealand

\begin{abstract}
Oral dysgeusia is relatively common, and may be caused by a number of factors. Zinc is a trace element that is critical for many enzymatic activities inside the body. Zinc deficiency is one of the causes of oral dysgeusia. The purpose of this study was to report three cases of oral dysgeusia. Haematological investigation revealed reduction in serum zinc level in all patients. They were prescribed with zinc supplement. Symptoms improved after a month of oral zinc supplementation. Zinc supplement appears to restore oral disturbance due to zinc deficiency and idiopathic taste disorders. However, we still cannot rule the placebo effect.
\end{abstract}

Keywords: Oral Dysgeusia; Taste Disorders; Zinc Deficiency; Zinc Supplement

Abbreviations: GP: General Practitioner; BMS: Burning Mouth Syndrome

\section{Introduction}

Nutritional problems are dependent on an individual's ability to access (aging, finances and refrigeration), eat (oral health), absorb (gastrointestinal disorders) and store food nutrients (demand for nutrients vs. supply). Zinc is an important trace element that is necessary for many biochemical functions, including enzyme activities, maintenance of the structural integrity of proteins and regulation of gene expression [1]. In general, zinc deficiency can cause problems of integumentary, gastrointestinal, central nervous system, immune, skeletal, and reproductive systems [2]. Moreover, zinc deficiency has been associated with disturbance of special senses including vision, taste and smell [3]. Several studies have suggested that oral dysgeusia may be one of the important symptoms of zinc deficiency [4-9].

\section{Case reports}

\section{Case 1}

In August 2014, an 80-year-old female was referred by her medical general practitioner (GP) to the Oral Medicine Clinic (School of Dentistry, Dunedin, New Zealand) for evaluation and treatment of recurrent fissures and uncomfortable tongue of five months duration. The patient described changes in her tongue that she pointed to as being fissured areas. She described the condition as being intermittent burning sensation on the dorsal surface of her tongue bilaterally, although it was never completely asymptomatic. On the visual analogue scale, the burning sensation was 6 out of 10 . She had no history of xerostomia. She was treated with nystatin oral drops and oral itraconazole, however her medical GP had no positive swabs to confirm the diagnosis of oral candidosis. Medically, she had hypertension, gastroesophageal reflux disease, and asthma, and her medication were amlodipine, bendroflumethiazide, pantoprazole, fluticasone propionate inhaler and Symbicort inhaler (budesonide and eformoterol fumarate) respectively. She had experienced adverse reaction to spironolactone, candesartan cilexetil and cilazapril. She had no history of mental health issues. On examination there was no lymphadenopathy in the submental, submandibular and cervical region. Cranial nerve examination was unremarkable. Intraoral examination was normal, other than her tongue, which showed evidence of tooth ridging laterally and fissuring with evidence of geographic tongue on the dorsal and lateral surface of tongue. Salivary flow test was normal. A tongue smear test revealed no evidence of Candida infection. Laboratory 
investigations showed normal complete blood count, serum B12 and folate, and iron studies. However, she was low in serum zinc 8.7 $\mu \mathrm{mol} / \mathrm{L}$ (normal 10.0-17.0 $\mu \mathrm{mol} / \mathrm{L}$ ). Therefore, we prescribed $50 \mathrm{mg}$ zinc sulphate capsule daily to this patient for two months, and encouraged her to have zinc-rich diet. At the six weeks review appointment, her serum zinc was $11.6 \mu \mathrm{mol} / \mathrm{L}$ and patient reported her symptoms had improved significantly after two weeks zinc supplement. At three months review, no taste disturbances were reported.

\section{Case 2}

In February 2015, a 32-year-old female was referred by her general dentist to the Oral Medicine Clinic for evaluation and treatment of a seven months history of recurrent oral candidosis. She had an ectopic pregnancy and was treated with a single dose of methotrexate. Since then, she apparently had developed oral candidosis, and described lack of taste and intermittent burning sensation on the dorsal surface of her tongue bilaterally. She described the burning sensation was 5 out of 10 on visual analogue scale. She had tried a number of treatments including antifungal medications from the medical GP, probiotics and a change of diet. However, none of these treatments had relieved her symptom. Finally, she met a Naturopath who advised her that the oral candidosis could be the reaction with the mercury in the amalgam and suggested replacement of amalgam restorations. Medically, she was on no medication and had no known allergies. She had no history of mental health issues. On examination, there was no lymphadenopathy on submental, submandibular and cervical region. Cranial nerve examination was unremarkable. Intraoral examination was normal. Salivary flow test was normal. A tongue smear test revealed no evidence of Candida infection. Laboratory investigations showed normal complete blood count, serum B12 and folate, and iron studies. However, she was slightly low in serum zinc $9.9 \mu \mathrm{mol} / \mathrm{L}$ (normal 10.0-17.0 $\mu \mathrm{mol} / \mathrm{L}$ ). Therefore, we prescribed $50 \mathrm{mg}$ zinc sulphate daily for two months, encouraged her to have zinc-rich diet. At the review appointment six weeks later, her serum zinc was $12.4 \mu \mathrm{mol} / \mathrm{L}$ and she reported symptoms had improved significantly after 7 days zinc supplement. No taste disturbances were reported at the three months review appointment.

\section{Case 3}

In April 2017, a 46-years-old female was referred by her medical GP to the Oral Medicine Clinic for evaluation and treatment of one-year history of an uncomfortable mouth. She described reduction in her saliva, lack of taste, intermittent burning sensation and changes in her tongue that she pointed to as being whitecoated areas. She described the burning sensation was 7 out of 10 on visual analogue scale Medically, she was fit and healthy. She had no history of mental health issues. On examination, there was no lymphadenopathy in the submental, submandibular and cervical region. Cranial nerve examination was unremarkable. Intraoral examination was normal. Un-stimulated and stimulated salivary flows were within normal limits. A tongue smear test revealed no evidence of Candida infection. Laboratory investigations showed normal complete blood count, serum B12 and folate, and iron studies. However, she was low in serum zinc $8.0 \mu \mathrm{mol} / \mathrm{L}$ (normal $10.0-17.0 \mu \mathrm{mol} / \mathrm{L})$. A report was sent to her Medical GP. Her Medical GP therefore prescribed her $50 \mathrm{mg}$ zinc sulphate capsules daily for three months. At the review appointment six weeks later, her serum zinc was $12.6 \mu \mathrm{mol} / \mathrm{L}$ and she reported symptoms had improved significantly after two weeks. No taste disturbances were reported at the four months review.

\section{Discussion}

Table 1: Zinc content of foods (NZ nutrition foundation).

\begin{tabular}{|c|c|}
\hline Foods Rich in Zinc & Zinc (mg) \\
\hline 1 raw oyster & 1.5 \\
\hline 1 cup smoked mussels & 4.1 \\
\hline 1 grilled rump steak & 8.0 \\
\hline 1 roast chicken breast & 1.9 \\
\hline 1 wholegrain bread roll & 0.8 \\
\hline 1 cup cooked chickpeas & 1.4 \\
\hline 10 roasted peanuts & 1.2 \\
\hline 1 tablespoon pumpkin seeds & 1.1 \\
\hline 1/4 cup edam cheese & 1.0 \\
\hline 1 cup reduced fat milk & 1.0 \\
\hline
\end{tabular}

Table 2: Clinical manifestations of zinc deficiency.

\begin{tabular}{|c|}
\hline Anorexia \\
\hline Smell and taste disorders \\
\hline Growth impairment \\
\hline Reproductive dysfunction \\
\hline Wound healing impairment \\
\hline Impotence \\
\hline Depression, apathy \\
\hline Jitteriness \\
\hline Photophobia, nyctalopia, blepharitis \\
\hline Cutaneous lesion \\
\hline Nail hypoplasia \\
\hline Hair loss \\
\hline Diarrhea \\
\hline Immunodeficiency \\
\hline
\end{tabular}

Zinc is an important trace mineral for normal growth, the immune system, nervous system development and pregnancy [10]. Zinc is found in many food sources (Table 1). Zinc deficiency may lead to a wide range of signs and symptoms (Table 2). The causes of zinc deficiency are summarized in Table 3. In general, zinc deficiency is mainly caused by malnutrition, lower food intake, medication, availability of food, and gastrointestinal disorders [1116]. Zinc deficiency is defined as the serum or plasma zinc level is below $10.7 \mu \mathrm{M}(70 \mu \mathrm{g} / \mathrm{dl})(16)$. Zinc deficiency is a major health issue 
in the world. An estimated $20.5-25 \%$ of the world's population is at risk of inadequate zinc intake $[17,18]$. Although zinc deficiency in developed countries is not a common problem, the elderly are still at high risk due to several factors [19-21]. A study from Australia and New Zealand revealed that many adolescent girls had inadequate dietary intake of zinc, and this may lead to problems in growth, immune and cognitive function, work capacity, sexual maturation, pregnancy and bone mineralization [22]. In addition, a New Zealand study [23] found younger male children were at risk of suboptimal zinc status, which was consistent with other studies [24], and pacific school and Māori children had higher prevalence of low serum zinc concentrations [25]. However, lower zinc intake appears to be more significant in developing countries. A South African study showed low zinc dietary intakes and serum zinc concentrations in elderly persons [11].

Table 3: The causes of zinc deficiency.

\begin{tabular}{|c|c|}
\hline \multirow{2}{*}{$\begin{array}{c}\text { Impairment of oral intake or } \\
\text { absorption of zinc }\end{array}$} & Eating disorder \\
Primary biliary cirrhosis \\
Chronic liver disease \\
Chronic kidney disease \\
Pancreatic dysfunction \\
Inflammatory bowel diseases \\
Ingestion of drugs with metal- \\
chelating activity \\
\hline Burn injury \\
Diabetic ketoacidosis \\
Chronic renal disease \\
Chronic diarrhea \\
Sickle-cell disease \\
Hyperhidrosis \\
\hline
\end{tabular}

High prevalenceofzinc deficiencywasfoundinchildrenbelonging to low socioeconomic index in India and Mexico [26,27]. In China, approximately 100 million people suffered from zinc deficiency, particularly those persons living in rural areas [28]. Moreover, diseases and medications, such as angiotensin-converting-enzyme inhibitors and diuretics can alter zinc status, and causes excessive urinary zinc excretion [13,28-31]. In particular, serum zinc levels were significantly reduced in captopril-treated patients over three months [13]. Furthermore, phytic acid that mainly presents in the plant tissue, particularly bran and seeds, can reduce the absorption of zinc in the gastrointestinal tract, thus leading to increased faecal excretion of zinc [32]. Signs of zinc deficiency, including low zinc in plasma, taste disturbance and low plasma activity of thymulin may be associated with diabetes [33-36]. Low dietary zinc intakes and serum zinc level are also found to be correlated with subclinical atherosclerosis [37]. Serum zinc concentration has been widely used to assess zinc deficiency. However, several factors, including cancer, acute stress and inflammation can modify serum zinc level [38-41]. For example, a case report of Cronkhite-Canada syndrome demonstrated taste disturbance with normal range of plasmatic zinc levels recovered after zinc therapy [8]. Another report showed zinc supplement improved symptoms of taste disturbance patients that had normal serum zinc level [42]. Therefore, it has been suggested oral dysgeusia can occur even when serum zinc level is in the normal range [43].

\section{Zinc Deficiency and Oral Dysgeusia}

Taste is one of the five major senses in humans. There are five elements of taste perception: saltiness, sourness, bitterness, sweetness, and umaminess. The gustaoception is based on the detection of chemical simulants by the taste buds in the oral cavity. Taste buds are mainly located on the tongue, but they are also found on the soft palate, upper oesophgus and epiglottitis. The taste buds are innervated by the seventh, ninth and tenth cranial nerves. In general, gustaoception and olfacoception are considered less important than opthalmoception, audioception, and tactioception. However taste disturbance can affect the quality of life, lead to social and work related issues and, in extreme cases, may be associated with life-threatening problems [44-47]. Oral dysgeusia can be defined as a distortion of the gustaoception or persistent abnormal gustatory sensation in the absence of gustatory stimulation [4850]. Patients with oral dysgeusia often complain of bitter, sour, or metallic sensation on the tongue, and may be associated with ageusia, which is lack of taste, and hypogesusia, which is the decease of taste sensation. The taste disorder can be considered as one of the symptoms of neurological derangement [21]. The main causes of taste disorders are summarized in Table 4. Among these causative factors, drug-induced taste disorder and zinc deficiency are the most common [51].

Table 4: Causes of taste disorders.

\begin{tabular}{|c|c|}
\hline Physiological & $\begin{array}{c}\text { Atrophy of oral epithelium Increase } \\
\text { degrees of atrophy and fibrosis of acini } \\
\text { of the salivary gland Reduction of taste } \\
\text { buds }\end{array}$ \\
\hline \multirow{7}{*}{ Local: Dental Caries, periodontal } \\
diseases, candidosis, erythema \\
migrans, fissure tongue, glossitis, \\
dermatoses, denture faults \\
Systemic diseases: Stroke, Alzheimer's \\
disease, Parkinson's disease, \\
Depression, Diabetes mellitus types 1 \\
and 2, Hypo/hyperthyroidism,Chronic \\
renal failure, Acute and chronic \\
liver disease, cirrhosis, Sjögren's \\
syndrome, irritable bowel syndrome, \\
Gastroesophageal reflux disease, \\
Hiatus hernia, Inflammatory bowel \\
diseases, HIV
\end{tabular}


Zinc plays a significant role in the taste perception, as zinc deficiency in healthy persons can cause taste disturbance [52]. Zinc is found in high concentration in taste buds [53]. Although the primary role of zinc in dysgeusia is unknown, but it has been suggested that zinc is a cofactor of an enzyme that involves in alkaline phosphatase activity in the membrane of taste bud. Moreover, zinc might influence gustin concentration by direct or indirect interacting carbonic anhydrase VI, which may affect the production of taste buds [50,54]. It has been suggested that zinc deficiency decrease the rate of taste buds proliferation and regeneration [55,56]. Another observation from zinc deficient rats showed lower carbonic anhydrase activity on tongue epithelium and submandibular gland [57]. Therefore, zinc deficiency may induce changes in the number, size, and structure of the taste bud cells, as well as decreases in the nerve sensitivity $[57,58]$.

Zinc supplement can improve the symptoms of taste disorders that are caused by zinc deficiency and idiopathic taste disorders $[7,42]$. A study in Europe showed zinc supplement $30 \mathrm{mg}$ daily over 6 months) improved salt taste acuity in persons over the age of 70 years [20]. A randomized clinical trial revealed zinc supplement (20mg/day over 3 months) appeared to have beneficial effects on general gustatory function and general mood compared to the control group [50]. The recommended daily zinc supplement (25$100 \mathrm{mg}$ ) appears to be an effective treatment for taste dysfunction [59]. After zinc supplementation, the serum zinc levels remains constant and this may due to the fact that zinc is transported into cells [60].

\section{Psychological Factors}

Several studies have shown that patients suffer from psychological disorders, such as mood disorders and anxiety disorders have higher risk than general population in developing unexplained somatic symptoms [61,62]. Psychogenic oral-facial dysaesthesia such as burning mouth syndrome (BSM) is an unpleasant burning, pricking sensation with no obviously organic causes [63]. Study has been suggested that psychological factors play an important role in the aetiology of BSM, however the exact relationship remains unclear. A number of medications have been tried to reduce the symptoms of BMS patients. Selective serotonin reuptake inhibitors found to be the most effective drugs for BMS [64]. A Cochrane review has shown that cognitive behavioral therapy can also reduce BMS symptoms [65]. These implied BMS might belong to somatoform pain disorders. In addition, one study found the acute stress event could set off the BMS in patients who have pre-existing psychological factors [66]. All patients denied any mental health problems, with clearly reduction in serum zinc in this case series. However, given that psychogenic factors, such as anxiety and depression are important in oro-facial dysaesthesia in which dysgeusia is often also reported the placebo effect of the provision of zinc supplementation maybe a source of bias [67].

\section{Conclusion}

Adequate serum zinc level is critically important for human health. Since zinc is involved in numerous enzymatic activities, it could affect taste through its role in those biochemical reactions. Zinc supplement appears to restore oral disturbance due to zinc deficiency and idiopathic taste disorders. However, we still cannot rule the placebo effect. Long-term review of these patients is recommended.

\section{References}

1. Trumbo P, Yates AA, Schlicker S, Poos M (2001) Dietary reference intakes: vitamin $\mathrm{A}$, vitamin $\mathrm{K}$, arsenic, boron, chromium, copper, iodine, iron, manganese, molybdenum, nickel, silicon, vanadium, and zinc. Journal of the American Dietetic Association 101(3): 294-301.

2. Tuerk MJ, Fazel N (2009) Zinc deficiency. Current opinion in gastroenterology 25(2): 136-143.

3. Russell RM, Cox ME, Solomons N (1983) Zinc and the special senses. Annals of internal medicine 99(2): 227-239.

4. Henkin RI, Bradley DF (1970) Hypogeusia corrected by $\mathrm{Ni}^{++}$and $\mathrm{Zn}^{++}$. Life Sciences 9(12): 701-709.

5. Mahajan SK, Prasad AS, Rabbani P, Briggs WA, McDonald FD (1982) Zinc deficiency: a reversible complication of uremia. The American journal of clinical nutrition 36(6): 1177-1183.

6. Henkin RI, Schecter PJ, Friedewald WT, Demets DL, Raff MA (1976) double blind study of the effects of zinc sulfate on taste and smell dysfunction. The American journal of the medical sciences 272(3): 285299.

7. Sakai F, Yoshida S, Endo S, Tomita H (2002) Double-blind, placebocontrolled trial of zinc picolinate for taste disorders. Acta otolaryngologica Supplementum 546: 129-133.

8. Yoshida S, Tomita H (2002) A case of Cronkhite-Canada syndrome whose major complaint, taste disturbance, was improved by zinc therapy. Acta oto-laryngologica Supplementum 546: 154-158.

9. Yagi T, Asakawa A, Ueda H, Ikeda S, Miyawaki S, et al. (2013) The role of zinc in the treatment of taste disorders. Recent patents on food, nutrition \& agriculture 5(1): 44-51.

10. Brown KH, Rivera JA, Bhutta Z, Gibson RS, King JC, Lonnerdal B, et al. (2004) International Zinc Nutrition Consultative Group (IZiNCG) technical document \#1. Assessment of the risk of zinc deficiency in populations and options for its control. Food and nutrition bulletin 25(1 Suppl 2): 99-203.

11. Oldewage Theron WH, Samuel FO, Venter CS (2008) Zinc deficiency among the elderly attending a care centre in Sharpeville, South Africa. Journal of human nutrition and dietetics : the official journal of the British Dietetic Association 21(6): 566-574.

12. Golik A, Zaidenstein R, Dishi V, Blatt A, Cohen N, et al. (1998) Effects of captopril and enalapril on zinc metabolism in hypertensive patients. Journal of the American College of Nutrition 17(1): 75-78.

13. Golik A, Modai D, Averbukh Z, Sheffy M, Shamis A, et al. (1990) Zinc metabolism in patients treated with captopril versus enalapril. Metabolism: clinical and experimental 39(7): 665-667.

14. Wapnir RA (2000) Zinc deficiency, malnutrition and the gastrointestinal tract. The Journal of nutrition 130(5S Suppl): 1388s-1392s.

15. Semrad CE (1999) Zinc and intestinal function. Current gastroenterology reports 1(5): 398-403. 
16. Haase H, Mocchegiani E, Rink L (2006) Correlation between zinc status and immune function in the elderly. Biogerontology 7(5): 421-428.

17. Wuehler SE, Peerson JM, Brown KH (2005) Use of national food balance data to estimate the adequacy of zinc in national food supplies: methodology and regional estimates. Public Health Nutrition 8(7): 812819.

18. Maret W, Sandstead HH (2006) Zinc requirements and the risks and benefits of zinc supplementation. Journal of Trace Elements in Medicine and Biology 20(1): 3-18.

19. Andriollo Sanchez M, Hininger Favier I, Meunier N, Toti E, Zaccaria M, et al. (2005) Zinc intake and status in middle-aged and older European subjects: the ZENITH study. European journal of clinical nutrition. 59: 37-41.

20. Stewart Knox BJ, Simpson EEA, Parr H, Rae G, Polito A, et al. (2008) Taste acuity in response to zinc supplementation in older Europeans. British Journal of Nutrition 99(1): 129-136.

21. Ikeda M, Ikui A, Komiyama A, Kobayashi D, Tanaka M (2008) Causative factors of taste disorders in the elderly, and therapeutic effects of zinc. The Journal of laryngology and otology 122(2): 155-160.

22. Gibson RS, Heath ALM, Ferguson EL (2002) Risk of suboptimal iron and zinc nutriture among adolescent girls in Australia and New Zealand: causes, consequences, and solutions. Asia Pacific journal of clinical nutrition 11(3): 543-552.

23. Gibson RS, Manger MS, Krittaphol W, Pongcharoen T, Gowachirapant S, et al. (2007) Does zinc deficiency play a role in stunting among primary school children in NE Thailand? The British journal of nutrition 97(1): 167-175.

24. Ruz M, Castillo Duran C, Lara X, Codoceo J, Rebolledo A, et al. (1997) A 14-mo zinc-supplementation trial in apparently healthy Chilean preschool children. Am J Clin Nutr 66(6): 1406-1413.

25. Gibson RS, Bailey KB, Parnell WR, Wilson N, Ferguson EL (2011) Higher risk of zinc deficiency in New Zealand Pacific school children compared with their Maori and European counterparts: a New Zealand national survey. The British journal of nutrition 105(3): 436-446.

26. Kapil U, Jain K (2011) Magnitude of zinc deficiency amongst under five children in India. Indian journal of pediatrics 78(9): 1069-1072.

27. Villalpando S, Garcia Guerra A, Ramirez Silva CI, Mejia Rodriguez F, Matute G, et al. (2003) Iron, zinc and iodide status in Mexican children under 12 years and women 12-49 years of age. A probabilistic national survey. Salud publica de Mexico 45(4): 520-529.

28. Ma G, Jin Y, Li Y, Zhai F, Kok FJ, et al. (2008) Iron and zinc deficiencies in China: what is a feasible and cost-effective strategy? Public Health Nutr 11(6): 632-638.

29. Golik A, Averbukh Z, Cohn M, Maor J, Berman S, et al. (1990) Effect of diuretics on captopril-induced urinary zinc excretion. European journal of clinical pharmacology 38(4): 359-361.

30. Golik A, Modai D, Weissgarten J, Cohen N, Averbukh Z, et al. (1987) Hydrochlorothiazide-amiloride causes excessive urinary zinc excretion. Clinical pharmacology and therapeutics 42(1): 42-44.

31. Reyes AJ, Olhaberry JV, Leary WP, Lockett CJ, van der Byl K (1983) Urinary zinc excretion, diuretics, zinc deficiency and some side-effects of diuretics. South African medical journal. Suid-Afrikaanse tydskrif vir geneeskunde 64(24): 936-941.

32. Couzy F, Mansourian R, Labate A, Guinchard S, Montagne DH, et al (1998) Effect of dietary phytic acid on zinc absorption in the healthy elderly, as assessed by serum concentration curve tests. British Journal of Nutrition 80(2): 177-182.

33. Mooradian AD, Morley JE (1987) Micronutrient status in diabetes mellitus. The American journal of clinical nutrition 45(5): 877-895.
34. Moutschen MP, Scheen AJ, Lefebvre PJ (1992) Impaired immune responses in diabetes mellitus: analysis of the factors and mechanisms involved. Relevance to the increased susceptibility of diabetic patients to specific infections. Diabete \& metabolism 18(3): 187-201.

35. Pai LH, Prasad AS (1988) Cellular zinc in patients with diabetes mellitus. Nutrition Research 8(8): 889-897.

36. Strain JJ (1991) Disturbances of micronutrient and antioxidant status in diabetes. Proceedings of the Nutrition Society 50(3): 591-604.

37. Yang YJ, Choi BY, Chun BY, Kweon SS, Lee YH, et al. (2010) Dietary zinc intake is inversely related to subclinical atherosclerosis measured by carotid intima-media thickness. British Journal of Nutrition 104(8): 1202-1211.

38. Tian X, Zheng Y, Li Y, Shen Z, Tao L, et al. (2014) Psychological stress induced zinc accumulation and up-regulation of ZIP14 and metallothionein in rat liver. BMC gastroenterology 14: 32.

39. Oakes EJ, Lyon TD, Duncan A, Gray A, Talwar D, et al. (2008) Acute inflammatory response does not affect erythrocyte concentrations of copper, zinc and selenium. Clinical nutrition (Edinburgh, Scotland) 27(1): 115-120.

40. Prasad AS (2009) Zinc: role in immunity, oxidative stress and chronic inflammation. Current opinion in clinical nutrition and metabolic care 12(6): 646-52.

41. Prasad AS (2009) Impact of the discovery of human zinc deficiency on health. Journal of the American College of Nutrition 28(3): 257-265.

42. Yoshida S, Endo S, Tomita H (1991) A double-blind study of the therapeutic efficacy of zinc gluconate on taste disorder. Auris, nasus, larynx 18(2): 153-61.

43. Takeda N, Takaoka T, Ueda C, Toda N, Kalubi B, Yamamoto S (2004) Zinc deficiency in patients with idiopathic taste impairment with regard to angiotensin converting enzyme activity. Auris, nasus, larynx 31(4): 425428 .

44. Schiffman SS (1983) Taste and smell in disease (first of two parts). The New England Journal of medicine 308(21): 1275-1279.

45. Henkin RI (1994) Drug-induced taste and smell disorders. Incidence, mechanisms and management related primarily to treatment of sensory receptor dysfunction. Drug safety: an international journal of medical toxicology and drug experience 11(5): 318-377.

46. Ackerman BH, Kasbekar N (1997) Disturbances of taste and smell induced by drugs. Pharmacotherapy 17(3): 482-96.

47. Heckmann JG, Heckmann SM, Lang CJ, Hummel T (2003) Neurological aspects of taste disorders. Archives of neurology 60(5): 667-671.

48. Deems DA, Doty RL, Settle RG, Moore-Gillon V, Shaman P, et al. (1991) Smell and taste disorders, a study of 750 patients from the University of Pennsylvania Smell and Taste Center. Archives of otolaryngology-head \& neck surgery 117(5): 519-528.

49. Brand JG (2000) Within reach of an end to unnecessary bitterness? The Lancet 356(9239): 1371-1372.

50. Heckmann SM, Hujoel P, Habiger S, Friess W, Wichmann M, et al. (2005) Zinc gluconate in the treatment of dysgeusia--a randomized clinical trial. Journal of dental research 84(1):35.

51. Ikeda M, Hirai R, Shigihara S, Ikui A (2008) Taste Disorders and Zinc Deficiency. International Journal of Oral-Medical Sciences 6(3): 105-111.

52. Law J, Nelson N, Henkin R (1983) Zinc localization in taste bud membranes. Biological Trace Element Research 5(3): 219-224.

53. Henkin RI, Martin BM, Agarwal RP (1999) Efficacy of exogenous oral zinc in treatment of patients with carbonic anhydrase VI deficiency. The American journal of the medical sciences 318(6): 392-405. 
54. Heckmann SM, Hujoel P, Habiger S, Friess W, Wichmann M, et al. (2005) Zinc gluconate in the treatment of dysgeusia--a randomized clinical trial. J Dent Res 84(1): 35-38.

55. Hamano H, Yoshinaga K, Eta R, Emori Y, Kawasaki D, et al. (2006) Effect of polaprezinc on taste disorders in zinc-deficient rats. BioFactors (Oxford, England) 28(3-4): 185-193.

56. Komai M, Goto T, Suzuki H, Takeda T, Furukawa Y (2000) Zinc deficiency and taste dysfunction; contribution of carbonic anhydrase, a zincmetalloenzyme, to normal taste sensation. Bio Factors 12(1-4): 65-70.

57. Chou HC, Chien CL, Huang HL, Lu KS (2001) Effects of zinc deficiency on the vallate papillae and taste buds in rats. Journal of the Formosan Medical Association. Taiwan yi zhi 100(5): 326-335.

58. Heyneman CA (1996) Zinc deficiency and taste disorders. The Annals of pharmacotherapy 30(2): 186-187.

59. Aliani M, Udenigwe C, Girgih A, Pownall T, Bugera J, Eskin MA (2013) Zinc Deficiency and Taste Perception in the Elderly. Critical Reviews in Food Science and Nutrition 53(3): 245-250.

60. Kapfhammer HP (2006) Somatic symptoms in depression. Dialogues in Clinical Neuroscience 8(2): 227-239.
61. Lieb R, Meinlschmidt G, Araya R (2007) Epidemiology of the association between somatoform disorders and anxiety and depressive disorders: an update. Psychosomatic medicine 69(9): 860-863.

62. Moisset X, Calbacho V, Torres P, Gremeau Richard C, Dallel R (2016) Cooccurrence of Pain Symptoms and Somatosensory Sensitivity in Burning Mouth Syndrome: A Systematic Review. PloS one 11(9): e0163449.

63. Fleuret C, Le Toux G, Morvan J, Ferreira F, Chastaing M, et al. (2014) Use of selective serotonin reuptake inhibitors in the treatment of burning mouth syndrome. Dermatology Basel, Switzerland 228(2): 172-176.

64. Zakrzewska JM, Forssell H, Glenny AM (2005) Interventions for the treatment of burning mouth syndrome. The Cochrane database of systematic reviews 1: Cd002779.

65. Hakeberg M, Hallberg LR, Berggren U (2003) Burning mouth syndrome: experiences from the perspective of female patients. European journal of oral sciences 111(4): 305-311.

66. Imoscopi A, Inelmen E, Sergi G, Miotto F, Manzato E (2012) Taste loss in the elderly: epidemiology, causes and consequences. Aging Clinical and Experimental Research 24(6): 570-579.

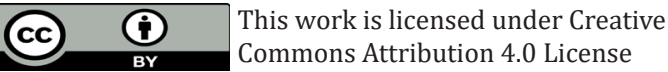

To Submit Your Article Click Here:

Submit Article

DOI: 10.32474/MADOHC.2018.02.000146

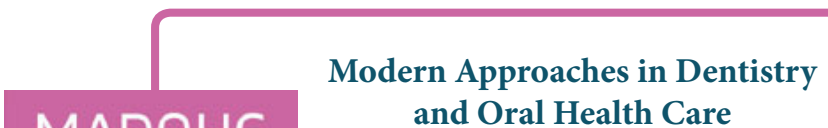

\section{Assets of Publishing with us}

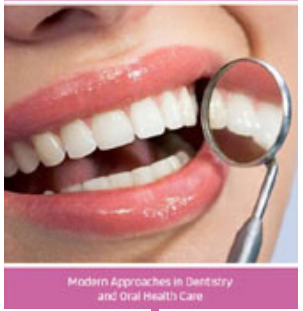

- Global archiving of articles

- Immediate, unrestricted online access

- Rigorous Peer Review Process

- Authors Retain Copyrights

- Unique DOI for all articles 